\title{
Foreword for the special issue Fish Research in Latin America: Biodiversity, and Basic and Applied Physiology
}

\author{
Ana T. M. Viveiros
}

Received: 1 July 2008/Accepted: 1 July 2008/Published online: 6 August 2008

(C) Springer Science+Business Media B.V. 2008

Last year, during the 8th International Symposium on Reproductive Physiology of Fish in Saint Malo, France, Prof. Dr. Henk J. Th. Goos, the editor of Fish Physiology and Biochemistry, invited me to organize this special issue on basic and applied fish research carried out in Latin America. Following Dr. Goos thoughts, I invited several researchers on different topics and from different nationalities to write about their experience for this special issue. The invitation was warmly received and many scientists have contributed.

The entire northern half of the South American continent, known as the Amazon Basin, is drained by the Amazon River and its tributaries. The basin is located mainly in Brazil (corresponding to $54 \%$ of the country), and extends into Peru, Bolivia, Colombia, and other countries. In this basin we can find amazing fish species such as the giant air-breathing pirarucu or paiche Arapaima gigas that can reach up to $200 \mathrm{~kg}$ body weight, the extremely aggressive piranha (various species of the genus Serrasalmus), as well as aquarium species such as freshwater angelfish Pterophyllum scalare and discus Symphysodon discus, and many species of fisheries interest. However, Latin America is more than the Amazon basin. There are also fish species adapted to floodplain areas caused by changes in the annual hydrological cycle of various rivers in Venezuela, Argentina, and Brazil, and marine and freshwater species coping with low temperatures from the Southern Neotropics and Patagonia, as well as with tropical temperatures from Mexico, Central America, and the north of South America, just to mention a few examples.

This variety of fish fauna became the research topic of many different laboratories spread over the continent. Most of the available information, however, is published in local journals, bulletins, and proceedings, mostly written in Portuguese or Spanish, with limited access to international readers. The purpose of this compilation was, therefore, to present the Latin America contribution in a single volume in the journal Fish Physiology and Biochemistry.

I thank Dr. Goos for the invitation to organize this issue. During its compilation, I had the great opportunity to contact several researchers who I knew only by name. I also want to express my gratitude to all the contributors for accepting my invitation and submitting their manuscripts on time. I hope the international community will find this issue very interesting and useful.
A. T. M. Viveiros ( ()

Animal Sciences Department, Federal University of Lavras, UFLA, Lavras, MG 37200-000, Brazil e-mail: ana.viveiros@ufla.br 